\title{
From the Consensus Reforms to Reforms for Protected and Inclusive Employment
}

\section{Victor Tokman}

\begin{abstract}
1 Introduction
This article analyses the evolution of labour markets in Latin America during the reform period from the late 1980 s to the present. The first part briefly reviews the objectives of the labour reforms included in the package of the Washington Consensus and identifies some specific reforms introduced in Latin America following this orientation. In the second part, the effects of these reforms are analysed, concentrating mainly on labour precariousness and exclusion. The article relates this analysis to the expansion of the concept from informal sector to informal economy. Finally, some suggestions are made for key elements of a strategy that aims at protected and inclusive employment.
\end{abstract}

\section{Labour reforms in Latin America: one component in a structural reform package}

Labour reforms were introduced as a second generation of the reform package aimed at structurally adjusting the Latin American economies following the debt crisis of the early 1980s. They were guided by three main orientations: globalisation, privatisation and liberalisation. Countries would pass from closed to open economies, from dominant state participation in the economy to a subsidiary role, and from highly regulated to free markets. Labour was not included in the first generation of the reforms and only at the end of the 1980s, when the economies failed to recover as expected, were the failures attributed to labour market rigidities and labour reform became a priority.

Labour reforms were introduced to increase flexibility in the labour market and to reduce the cost of labour. Both were considered key components to improve competitiveness based on a diagnosis that wages and labour costs were too high. The prevailing contract for waged workers in formal enterprises was an indefinite labour contract, which ensured stability in the job for a long period through high firing costs. It included prior notice and indemnities (compensation is one month per year worked with a ceiling of 11 months) for the years worked, and constituted a simple and effective way to ensure protection in countries where unemployment compensation or social policies with this objective were non-existent or of limited coverage. Such contracts were useful in highly protected economies, but globalisation and open markets introduced constraints that impinged on the capacity to adjust. The cost of firing under the permanent contract in Latin America was almost double that prevailing in OECD countries (Heckman and Pages 2004); labour regulations are 26 per cent higher ${ }^{1}$ than in OECD countries and exceed by 54 per cent those in East and Pacific Asia (Loayza et al. 2006).

The labour reforms thus aimed to reduce firing costs and to eliminate other rigidities in times of adjustment. As acquired rights could not be affected, the strategy followed was the introduction of 'flexibility at the margin' (Tokman and Martínez 1999) by introducing atypical contracts for new hiring and reducing the cost of dismissals. In addition, contracts were for a fixed period as an alternative to the permanent contract. The logic behind the reforms was based on two assumptions. The first was that foreign investment would be attracted by cheap labour, and the second that competitive advantage could be developed based on cheap labour. As was later demonstrated, the assumptions were wrong, since foreign capital is not attracted by low labour costs, but by the availability of skilled workers (with the exception of maquilas) (OECD 2002); and even if 


\section{Figure 1 Flexibility and labour costs reduction, 1990-7*}

\section{Wage workers by type of contract}

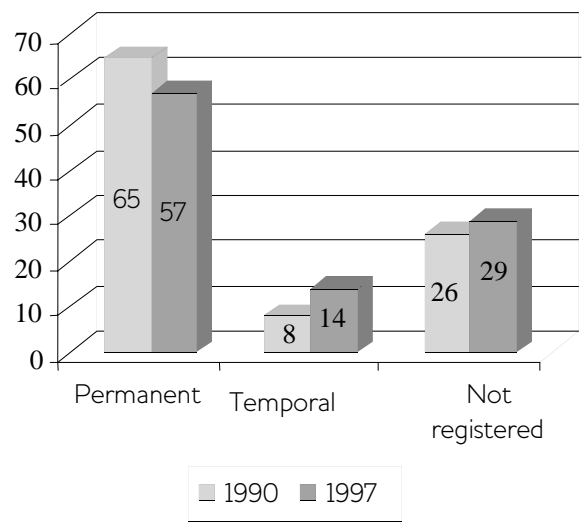

Labour costs by firm size

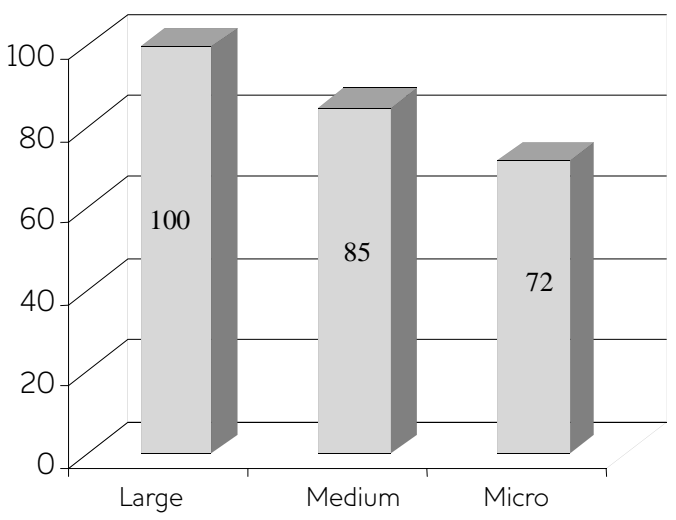

Labour costs by contract type

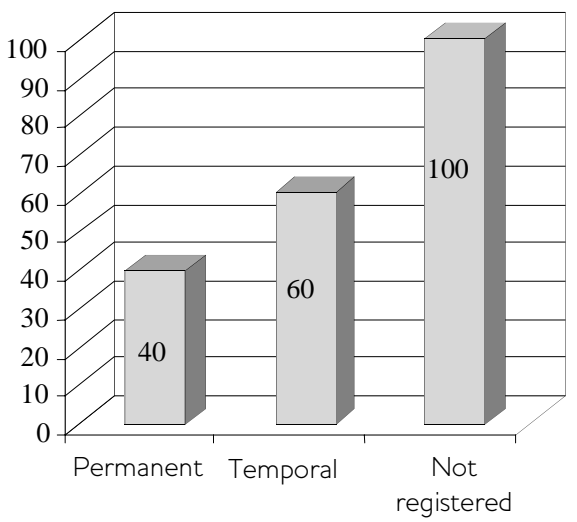

Average labour costs relative to cost under permanent contracts

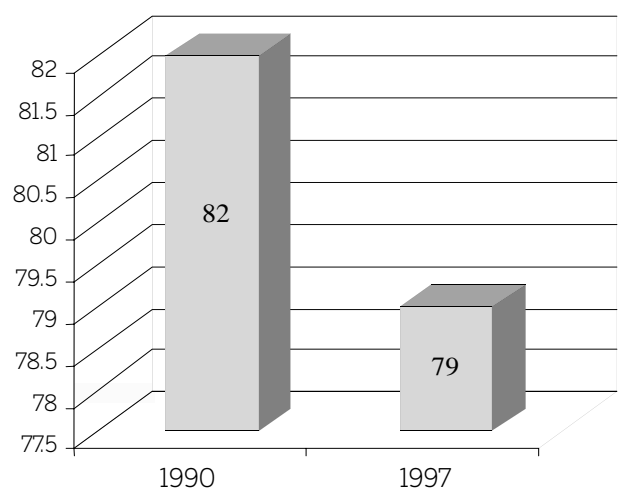

'Average for Argentina, Colombia, Chile and Peru Source Tokman and Martínez (1999).

labour costs could be reduced, they would remain above the costs prevailing in Asian countries, both because of relative factor endowments with abundant natural resources, and due to more advanced system of labour relations in most countries in the region. Besides, the Asian countries have also demonstrated that low labour costs were important to gain access to markets in the early phases of development, but innovation and product design have been continuously added to make them dynamic competitors in world markets.

Eleven of the 17 Latin American countries introduced reforms aiming at greater labour flexibility, affecting 70 per cent of wage employment (Vega-Ruiz 2005).
Even before the promotion of such labour reforms, Spain had introduced a major reform in 1981, searching for flexibility at the margin by introducing 12 new modalities of special contracts that involved a reduction in firing costs and in the contributions to social security during the first two years, focusing on employees below 30 and above 45 years old, on the long-term unemployed and on those with disabilities. Colombia in 1990, Argentina in 1991 and 1995 and Peru in 1993, were early reformers following the same orientation, introducing alternative labour contracts of limited duration and promotional clauses for specific groups. ${ }^{2}$ Argentina in particular eliminated or reduced the contributions to social security. Peru introduced nine new modalities but also innovated by 


\section{Figure 2 Total coverage by work contract}

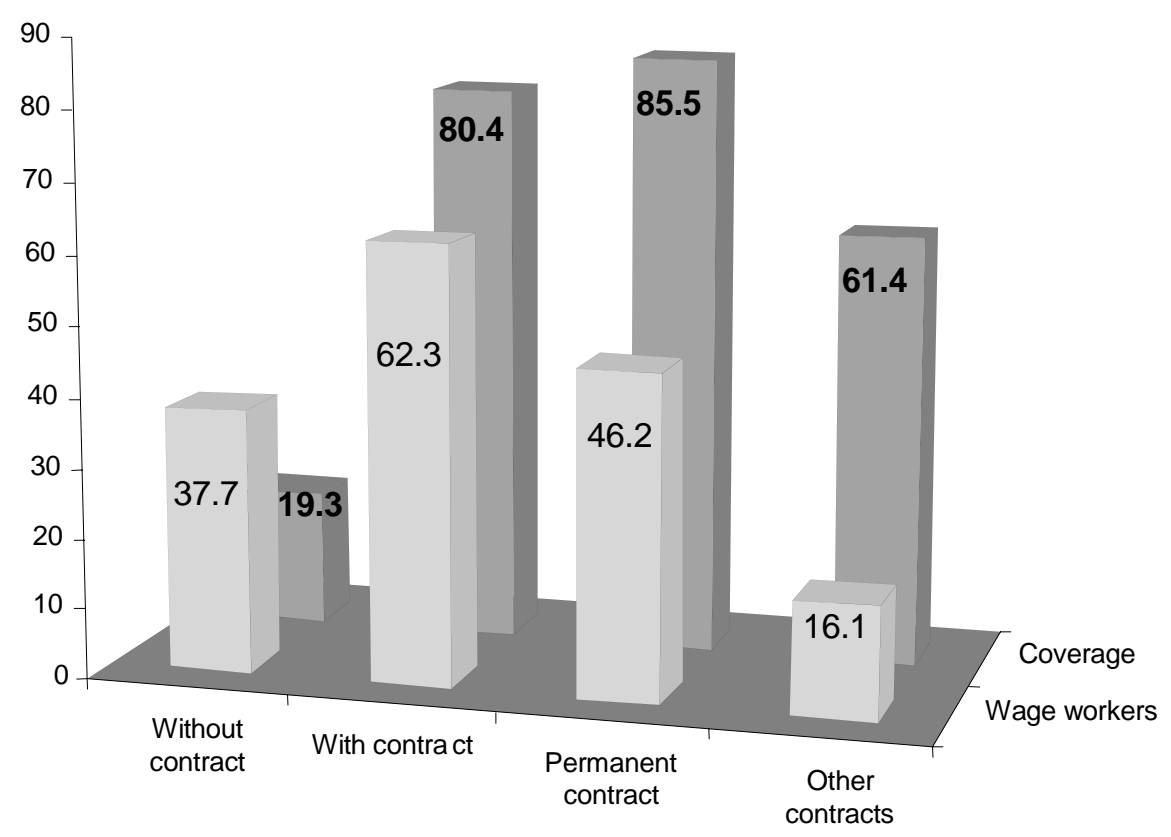

The first row columns (light grey) refer to waged-workers in each category as percentages of total waged-workers. The second row columns (dark grey) refer to social protection coverage as a percentage of the total waged-workers in the respective category. The indicator used for social protection is the contribution to pensions.

Sources Data processed by ECLAC on the basis of national household surveys of seven countries: Argentina, Bolivia, Chile, Ecuador, Guatemala, Mexico and Panama.

promoting labour decentralisation by creating firms supplying temporary workers, firms providing services and workers cooperatives. These in effect constituted ways to legally operate beyond labour regulations.

The guidelines for labour reforms followed the trend of labour relations systems in developed countries, seeking more flexibility, decentralising collective bargaining, upgrading skills, linking wages to performance, all within a context of declining trade union coverage (Locke et al. 1995). In terms of strategies to increase competitiveness, there is a coexistence of those based on cost reduction and those targeted at adding value to production. The experience of big corporations recommends starting with the former and then advancing to the latter. The evolution from one strategy to the other however, is not automatic. In countries where trade unions are weak, cost reduction strategies predominate and the transition to added value is delayed. The result is that the short run trade-off tends to become permanent.

\section{The effects of labour reform}

3.1 Employment, contracts and labour costs

Employment under atypical contracts increased during the labour reform period and at the same time, unregistered workers increased. Employment under permanent contracts decreased. Labour costs decreased, because of labour contract substitution, as well as the reduction of contributions charged to the wage bill.

Figure 1 shows that the contract structure became more flexible and labour costs decreased between 1990 and 1997, the period when labour reforms were mostly applied. Wage employment increased mainly as a result of the increasing share of workers with atypical contracts, but was compensated for partly by the decrease in employment under permanent contracts. Employment without contracts or unregistered employment expanded mostly in microenterprises, while fixed term employment increased mainly in larger size firms. According to 
household surveys around the year 2000 the increase in workers without contracts continued, reaching 74 per cent in Peru and 35.8 per cent in Argentina. ${ }^{3}$ This was associated with the introduction of labour reforms in search of flexibility in an environment of weak labour inspection, which was further weakened by the widely accepted diagnosis attributing rigidities to legislation. This was read by the employers as a signal to hire new entrants without contracts.

Labour costs decreased as a result of the increase of workers with atypical contracts and without contracts. Labour costs for a worker without a contract were reduced by around 60 per cent in comparison to one with a permanent contract, while the labour cost of workers with a temporary contract allowed for a reduction of 40 per cent in comparison to a permanent worker. In Argentina, these changes resulted in a decrease of non-wage costs from 53 per cent in 1990 to 40 per cent in 2003; while in Peru the cost reduction was from 34 to 22 per cent between 1989 and 2001 (Chacaltana 2005).

\subsection{Instability, uncertainty and unprotected labour}

Labour flexibility in a volatile macroeconomic environment facilitates adjustment but results in decreased labour tenure and a higher job turnover. Job tenure in Latin America at the end of the 1990s was 7.6 years compared with 10.5 years in OECD countries. The IDB estimated a job turnover rate of between 16 and 35 per cent for 12 countries and in Mexico and Brazil, the rate was 33 per cent. In a given year, one in three jobs are created and destroyed. In Peru, labour tenure decreased from 7.5 years to 4 years following the reforms. Shorter tenure affects productivity, since incentives to invest in specific training are reduced.

Labour instability, particularly when social protection is insufficient, result in uncertainty. Perceptions tend to widen the expected instability. On average for Latin America in 2005, while 75 per cent of people interviewed worried about losing their job in the next 12 months, only 59 per cent responded that there had been one unemployed adult in the household during the last 12 months (Latinobarómetro 2005).

Finally, the lack of formally recognised employment relations and precariousness in the relationship, results in reduced social protection (Figure 2). Differences in social protection coverage for those workers with or without written contracts are

\section{Figure 3 Structure of the informal economy,}

\section{0-2005}

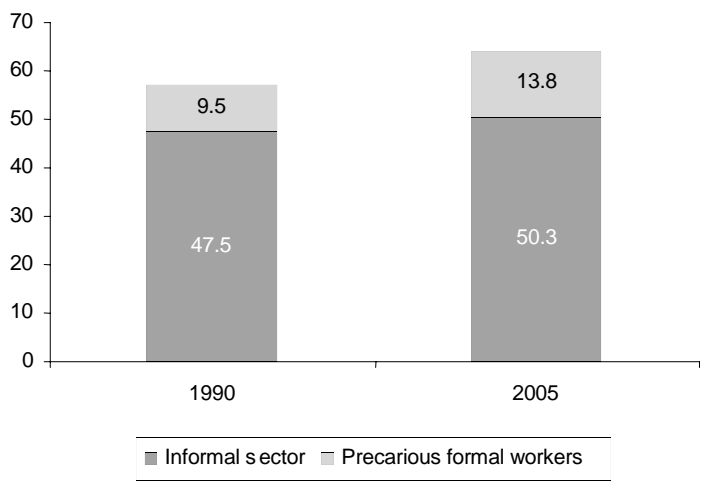

Sources and notes ECLAC on the basis of households' surveys and Tokman (2007). It includes 16 countries in 2005 and in 1990 for the informal sector. Precarious formal workers in 1990, refers to five countries. The percentage for 2005 does not significantly differ for five or 16 countries. It refers to the arithmetic mean.

substantial. ${ }^{4}$ On average, 19 per cent of workers without contract have access to social protection, while the likelihood of access to protection is more than four times higher for workers with contracts. The type of contract also matters. The permanent contract gives an 89 per cent probability of being covered by social protection, while atypical contracts result in a reduction in access to 61 per cent.

A total of 38 per cent of workers do not have a written labour contract and 16 per cent work under atypical contracts. However, two-thirds of those without contracts are in the informal sector and only 10 per cent among them have access to social protection. On the other hand, 78 per cent of the workers with atypical contracts are in the formal sector and 65 per cent among them have access to protection. This situation provides grounds for two conclusions. The first is that coverage problems are not only in the informal sector, because a significant and increasing number of workers labouring in the formal sector are affected. The second is that those most likely to be excluded from protection are in the informal sector.

The above observation led the ILO, 30 years after introducing the concept of the informal sector, to expand the concept from sector to informal 
economy. The informal economy is defined as 'all economic activities by workers and economic units that are - in law or in practice - not covered or insufficiently covered by formal arrangements' (ILO 2002). It includes both enterprise and work relationships, and it does not eliminate the informal sector but expands it to include all workers that are not sufficiently covered even if they are employed in formal units of production. It provides a framework to capture spurious decentralisation or subcontracting inside formal units of production.

The informal economy has expanded during the last decade and a half in Latin America. It went from 57 per cent of non-agricultural employment in 1990 to 64.1 per cent in 2005, with both the informal sector and precarious workers in the formal sector increasing, as can be seen in Figure 3. It can also be observed that the latter grew faster, closely connected to the increased precariousness during the reform period in Latin America. Close to 60 per cent of the expansion of the informal economy is explained by this factor.

\section{Towards a strategy for inclusion and opportunities}

Informality and social exclusion reflect poor access to resources, low incomes and vulnerability: they also constitute a market and a policy failure and particularly, a citizenship failure, since the people affected are denied entitlements to their economic, social and labour rights. $A$ renewed strategy for inclusion of those working in the informal economy is needed. ${ }^{5}$

The informal sector includes both enterprises and families engaging in productive activities, and the likelihood of progressing towards formal-sector status is determined mainly by a productive unit's capacity for growth. Similarly, the extent to which employment relations in the informal sector should be recognised and regulated depends on enterprises' ability to comply with obligations, which are directly linked to their economic success. For this reason, the development of informal-sector production and progress in the labour sphere must be addressed at the same time.

Workers in the informal economy are also directly or indirectly employed beyond the informal sector, in formal enterprises, where they are subject to insecurity and lack of labour and social protections.
Misguided labour reforms or ill-designed regulations in weak enforcement environments need to be corrected to improve compliance. Finally, protection of workers in the informal economy and especially those in the informal sector should be examined in relation to their contributory capacity to ensure adequate levels of coverage of health and old age risks.

\subsection{Regulation of informal activities}

Regulations designed with larger enterprises and more organised sectors in mind are inadequate for the needs and conditions of microenterprises. There is a need for adjustment and simplification to facilitate compliance. Bureaucratic difficulties hold up requests to open or close informal business activities, due to the numerous laws and regulations involved and administrative inefficiency. As pointed out in a recent ILO study (2006), these regulations apply generally to all enterprises, but the smaller ones are disproportionately affected, as they do not have the means to overcome the obstacles to doing business.

There are 2.6 times as many such regulations in Latin America as in OECD countries; only in Africa and the Middle East are such regulations more numerous (Loayza et al. 2006). There have been marked improvements in trade and financial sectors, while the largest backlog is found in the regulations governing business licences.

Simplifying bureaucratic procedures constitutes a way of bringing down access barriers. Numerous measures have been adopted to implement simplified registration regimes, both in terms of unifying registries and administrative steps towards compliance. Current trends point to the implementation of a 'single registry-single window' regime. This would reduce the cost of formalisation; however, the obstacles from bureaucratic vested interests to technical demands raised by oversight and enforcement actions should not be ignored.

There is room for action regarding the mechanisms for formalisation. An increasingly popular device is the recognition of property titles as a mechanism to have access to credit. The proposed innovation seeks to simplify the release of a legal property title and to adapt it to prevalent conditions of de facto ownership. This course entails disregarding contractual prerequisites and providing proof of property title, using alternative means of recognition, such as long-term usufruct, calling on witnesses and 
having boundaries recognised by third parties that might have conflicting interests. This addresses a major obstacle to access to credit, since collateral requirements, which usually involve assets, represent a major hurdle in a sector where 'property' is not formalised.

The separation of assets of the individual and the entrepreneur (an important step for microentrepreneurs) is usually achieved by creating firms of a diverse legal nature and diverse degrees of complexity. Requirements associated with this simple but crucial change to the patrimonial responsibility of micro-entrepreneurs entail a monetary cost, as well as compliance with a series of regulations, that render this enfranchising step towards formality a difficult one. This process could be simplified by conferring legal status to the entrepreneur along with the business licence (Fuentes 1998).

\subsection{Labour rights in informal enterprises}

Labour law does not fully apply to workers in the informal sector and few productive units are able to meet the obligations arising from the establishment of an employment relationship.

The share of workers without a contract or on atypical contracts is over 90 per cent in Bolivia and Guatemala, and reaches about 85 per cent in Mexico and Ecuador. Pension coverage extends to only 18 per cent of those occupied in the informal sector, compared with 68 per cent in the formal sector (Tokman 2006). This difference is partly explained by the poor pension coverage of own account workers. Although the difference between wage-employees is smaller, the coverage of those in microenterprises is still one-third of those in larger enterprises (CEPAL 2006). Most workers in the informal sector are not entitled to employment protection because their employment relationship is not legally recognised. On average for Latin America, 78 per cent of wage workers in microenterprises do not have a written labour contract. ${ }^{6}$

Microenterprises are less able to absorb the costs of employing workers on a formal basis. In Colombia, only 15 per cent of microenterprises paid any contribution and 76 per cent could not pay total labour costs. Sales would have to double to absorb these obligations (Gómez 1998). In Peru, only 15 per cent of microenterprises were in a position to absorb all labour costs. To do so their profits would decrease between 50 and 100 per cent. More than half of the microenterprises paid no non-wage labour costs at all and 49.5 per cent complied only partially with some obligations (Yañez 1998).

Recognition of the employment relationship would contribute to improved labour and social protection. This could be achieved with proof of the existence of unwritten contracts by registration of regular hours or periodic wage payments in the accounts or by witnesses. This would provide the workers with the necessary credentials to be entitled to protection and would encourage micro-entrepreneurs to acquire the necessary skills to do business on a proper basis. Recognising the existence of a formal employment relationship generates the pressure needed to manage the production unit as a proper business rather than a family enterprise.

This first step will, however, not be sufficient if the enterprise is unable to absorb the costs of compliance. Some adjustment to the existing legislation may be necessary to make it more applicable, but this should not be through deregulation: being more responsive to the need of microenterprises does not mean that existing labour conditions can be allowed to deteriorate.

In Argentina, Brazil and Peru, special systems for microenterprises have been introduced. Such differentiation may prove difficult to implement for reasons of regulatory inefficiency and as a matter of principle: they create opportunities for fiscal and labour law evasion and introduce barriers to microenterprise growth by setting maximum limits on capital investment. In labour law, such differentiation introduces issues of principle by accepting differential treatment of workers before the law depending on the size of the enterprise. $A$ single regulatory system would be preferable with regard to labour matters (ILO 1991). This does not exclude differential treatment for other related issues, such as the introduction of simplified tax regimes, preferential interest rates, or special regimes for collective bargaining.

These realities should be recognised, but this does not exclude intervention. A possible approach would be to introduce a compulsory minimum threshold on labour issues. An initial component should consist of fundamental labour rights as included in the ILO Declaration of 1998 (freedom of association and 
collective bargaining, elimination of forced and child labour and of discrimination in respect to employment and occupation). These amount to the transfer of human rights into the labour sphere. In addition, related aspects of working conditions could be included, as for example: minimum wage, hours of work and work-related accidents and illness.?

This minimum floor should be enforced for all workers in the informal sector independently of the size or form of the unit in which they work. This is not at odds with the notion of operating with a tolerance margin, which allows for the constraints encountered by informal sector production units. Such tolerance could be acceptable but should not be applied to the suggested minimum floor. The application of these rights should be monitored, promoted and controlled using procedures that take full account of the specific nature of each issue being regulated.

One possible model would be to establish an advance commitment to compliance, with targets used by the ILO to supervise international labour standards. Another would be to recognise that some non-compliance is due to ignorance of the legal obligations involved. The labour inspection should include a learning component, or as Chile has done since 2001, could substitute the fine with training for informal sector entrepreneurs under the supervision of the relevant labour institution. The ILO (2006) has also proposed another innovation based on the assumption that the effect of regulation is enhanced if there are several possible ways of enforcing compliance, allowing the problems to be monitored and solved in a gradual manner.

\subsection{Insecurity, vulnerability and atypical employment contracts}

Insecurity and vulnerability are linked to the absence of explicitly recognised employment relations, but also to situations governed by atypical labour contracts. This must be distinguished from the situation of workers whose employment relationships are ill-defined or not properly recognised by labour legislation.

Both have increased in recent decades to adapt to the new economic conditions under globalisation. Decentralisation of production and labour processes emerged as an instrument to decrease costs, particularly labour costs, as well as to increase productive efficiency. This contributed to a spurious decentralisation aimed at eroding compliance with labour regulations by diluting the definition of the employment relationship. At the same time, there was a need to adapt to a more open and volatile international economic environment. Adjustments were needed and the search for flexibility to diminish the costs involved became a priority.

As analysed above, labour reforms in Latin America introduced alternative contracts to the permanent employment contract with this objective. In general, these do not affect social protection as long as workers remain employed; nor are they illegal, as they were introduced by labour reforms which encouraged their use. In Argentina and Peru, there are no significant differences in non-wage labour costs among contracts. Their main effect has been insecurity about the continuity of the current contract. This insecurity affects the worker and the family as well as productivity, because of the loss of incentives to innovate and to upgrade skills. For this reason, while recognising that these contracts are necessary particularly to promote employment for women and young people, limits on their use should be introduced and efforts should focus on making long-term contracts more flexible.

Spain and Argentina have already followed this approach. Since the mid-1990s, both countries reformed the reforms. Spain restricted the use of fixed term contracts to collective bargaining and transferred the search for flexibility to the permanent contract, facilitating the judicial process of firing and reducing the costs involved. A new tripartite agreement was reached in 2006 reinforcing the new orientation and promoting the return to the permanent contract by converting fixed term contracts into a permanent one after 24 months of a contract with the same enterprise or successive contracts in the same post. It introduced additionally a 4 years bonus for long-term contracts given to women, young people and long duration unemployed and reduced contributions to social security. Argentina followed the same course in the reforms of 1998 and 2000, constraining the use of fixed term contracts, reducing indemnities in permanent contracts and extending the trial periods. In addition, contributions to social security were reduced in contracts for workers older than 45 years, younger than 24 years and women head of households. Brazil in 1998 also introduced atypical contracts but made them conditional upon the creation of new jobs in order to reduce the potential contract substitution 
and left it to collective bargaining to set upper limits on the number of contracts to be concluded.

\subsection{III-defined employment relationships and their regulation}

III-defined employment relationships are difficult to identify or are disguised or unprotected owing to gaps in labour regulations or compliance control. The rights and obligations of both parties are often not clear, which may result in loss of protection. Such cases are growing in number in the context of globalisation and decentralisation of production, which makes it necessary to establish workers' rights and to determine who the responsible employer is. Most enterprises involved in these relations are formal, but workers' rights in subordinated firms are not necessarily fully complied with. They are part of the informal economy. These hidden or ill-defined relations also exist between formal and informal units, introducing additional difficulties to their identification.

The ILO adopted an Employment Relationship Recommendation in 2006 (No. 198), recommending to 'formulate and apply a national policy for reviewing at appropriate intervals and, if necessary, clarifying and adapting the scope of relevant laws and regulations, in order to guarantee effective protection for workers who perform work in the context of an employment relationship'. The nature and extent of protection should be defined by national law or practice, or both, and should include scope, coverage and responsibility for implementation. To help determine the existence of an employment relationship, suggested indicators, other than the regular payment to the worker, include: that the work is carried out according to the instructions and under the control of another party; whether it is performed solely for the benefit of another person; whether it must be carried out personally by the worker, within specific working hours; and whether it required the worker's availability and involves the provision of tools and machinery by the party requesting the work.

The ILO also addressed home work and in 1996 adopted a Convention (No. 177) and a Recommendation which contributed to the formulation of a legal framework. Home work is a long established form of production which, in appearance, is work performed on own account or within a family structure. However, it often amounts to paid subordinate work performed outside the main enterprise but for the benefit of a subcontracting enterprise or for an intermediary. Such work is performed largely by women, with the help of family members and is not taken into account by labour legislation. The absence of a recognised employment relationship leaves the workers vulnerable and without negotiating power. The objective is to promote equal treatment between home workers and other wage earners, taking into account their special characteristics. This relates to the right of home workers to establish or join organisations of their own choosing and to take part in activities thereof (freedom of association), to protection against discrimination, the minimum age for admission to work employment, remuneration, protection in the field of occupational safety and health, social security and maternity protection.

In this connection, mention may be made of a recent law adopted in Chile to regulate subcontracting and suppliers of temporary staff. The law sets limits only on the supply of staff for short-term jobs and exceptional tasks. It requires enterprises to register and establish a guarantee fund to meet wage costs and contributions in case of non-compliance of labour obligations. For subcontracted firms, the responsibility lies with the subcontractor, but the law also places responsibilities on the main contractor and changes the present subsidiary into a joint responsibility. However, it provides the main enterprise with the right to require certification of compliance and to withhold from pending payments any amounts due in case of non-compliance.

\subsection{Social protection for informal workers}

Social protection coverage (health and pensions, as well as maternity) for informal workers requires strategies that include expanding coverage of present systems and the development of new instruments like insurance and pooling of resources for the excluded. India recently introduced a bill to regulate employment and service conditions of unorganised workers and to provide for their safety, social security, health and welfare, and introduced a Welfare Fund, funded by government and registered employers. In the Philippines the Statutory Social Security system and the health insurance plans have increased their coverage through voluntary schemes open to self-employed workers.

From a systemic perspective these rights should be granted to the people as citizens rather than as workers and awarded on universality principles. This 
has been the major change in the redesigning of the 'traditional model' in Latin America as well as in completing the private defined contribution pension systems by adding a solidarity pillar funded from public resources. The World Bank in its recently published report on informality (Perry et al. 2007), fully supported this change both in the case of health and pensions coverage. In the case of healthcare, it is recognised that as shocks that go uncovered impose significant costs to society, there is a case for providing minimum essential direct cover, de-linked from the labour contract and financed through general taxation. Similarly, in the case of insufficient income in old age, there are social costs involved that justify a minimum income support not associated with the labour contract. Bolivia is the only country in Latin America that has introduced a universal noncontributory pension (BONOSOL) and Brazil has a similar system for rural workers (FUNRURAL). ${ }^{8}$ Chile, a pioneer country in introducing the privatisation of the pension and health systems, is taking the lead in introducing a non-contributory pillar that guarantees a solidarity pension to all citizens over 65 years old.

\section{Notes}

* DPhil Oxford University. This article was presented to the IDS-WIEGO Workshop on 'Informal Work, Economic Growth and Social Protection', held in Sussex, 22-23 October 2007.

1 'Higher' is used to refer to 'heavier' regulatory burden. They refer to a synthetic index obtained as an average of related components normalised to vary between 0 and 1 .

2 Chile introduced reforms even earlier in 1978 and 1981 under the Pinochet dictatorship. Both included the promotion of flexibility but particularly affected collective labour rights in legislation that were de facto abolished.

3 A study made by the Minister of Labor Employment and Social Security of Argentina (2006) shows that 29.6 per cent of private employment in 1990 was without contract, increasing to reach a maximum of 43.4 per cent in 2004 and later decreasing to 39.8 per cent in 2005 .

\section{References}

Chacaltana, J. (2005) Dimensiones de la Productividad del Trabajo en las Empresas de América Latina. Un Estudio Comparativo de Argentina, Lima: Panamá y Perú, OIT, Oficina Regional para América Latina y el Caribe
Health is covered to a larger extent than pensions and achieves universality though a combination of different systems: social insurance in Costa Rica covers contributors and non-contributors, a public funded system in Cuba and a mix of public institutions, social security and private insurance in Uruguay, Brazil and Chile, among others. The latter has strengthened access to public health for all citizens by introducing an attention guarantee of 56 basic pathologies ( $A \cup G E$ ) in addition to the existing national health insurance (FONASA).

De-linking protection from labour participation would create opportunities to increase employment and improve business, while guaranteeing security. It would contribute to reducing the existing protection deficits but it will require sound fiscal policies and particularly, the adequate funding of decent health and pensions coverage. It should also include maternity and child care, given the potential effect on the early development of cognitive abilities and on the participation of women, particularly those from poor households, in the labour market.

4 Social protection is measured as proxy by the percentage of workers in each type of contractual situation that contributes to old age pensions.

5 See also Tokman (2007).

6 It includes 11 countries. In six of them, this percentage is higher than 90 per cent (CEPAL 2006).

7 This broader minimum threshold has been incorporated into the free trade agreements signed by the United States and various countries, including Mexico, Chile, all the countries of Central America and Dominican Republic, Peru, Panama, and Colombia (the latter two still pending of definitive adoption).

8 The public funds involved are the highest in Bolivia (1.2 per cent of GNP) and are estimated for the quasi-universal pension of Chile at 1.0 per cent, compared with the focused pensions in the Region that are usually below 0.5 per cent of GNP.

CEPAL (2006) La Protección Social de Cara al Futuro. Acceso, Financiamiento y Solidaridad, Santiago: CEPAL, Naciones Unidas

Fuentes, S. (1998) 'Sugerencias de Políticas para la Integración de los Sectores Informales de Micro y Pequeños Empresarios', in E. Chavez, A.M. Yañez, 
C. Luna, R. De la Flor, S. Fuentes and M. Robles (eds), Perú: El Sector Informal Frente al Reto de la Modernización, Lima: ILO

Gómez, L.R. (1998) 'Marco Legal, Caracterización y Políticas de Apoyo a la Microempresa en Colombia', in L.R. Gómez, G. Huertas and D. Olea (eds), Desafios de la Modernización y el Sector Informal Urbano. El Caso de Colombia, Working Paper 87, Lima: ILO

Heckman J. and Pages, C. (2004) Law and Employment: Lessons from Latin America and the Caribbean, Illinois: National Bureau of Economic Research, The University of Chicago Press, Chicago

ILO (2006) 'Business Environment, Labor Law and Micro - and Small Enterprises', Committee on Employment and Social Policy, Governing Body 297th Session, Geneva

ILO (2002) 'Decent Work and the Informal Economy', Report of the Director-General, International Labour Conference, ILO, Geneva, 3-20 June 2002

ILO (1991) 'Dilemma of the Informal Sector', Report of the Director-General presented at the 78th International Labour Conference, Geneva, June 1991

Latinobarómetro (2005) 1995-2005, Diez Años de Opinión Pública, Santiago

Loayza, N., Oviedo, A.M. and Servén, L. (2006) 'The Impact of Regulation on Growth and Informality: Cross Country Evidence', in Basudeb Guha-
Khasnobis, Ravi Kanbur and E. Orstrom (eds), Linking the Formal and Informal Economy: Concepts and Policies, Oxford: Oxford University Press Locke R., Kochan, T. and Piore, M. (1995) 'Replanteamiento del Estudio Comparado de las Relaciones Laborales: Enseñanzas de una Investigación Internacional', Revista Internacional del Trabajo 114: N2

OECD (2002) Employment Outlook 2002, Paris: Organisation for Economic Cooperation and Development

Perry, G., Maloney, W., Arias, O., Fajnzylberg P., Mason, A. and Saavedra, J. (2007) Informality: Exit and Exclusion, Washington DC: World Bank

Tokman, V.E. (2007) 'The Informal Economy, Insecurity and Social Cohesion in Latin America', International Labour Review 146.1-2

Tokman, V.E. (2006) Inserción Laboral, Mercados de Trabajo y Protección Social, Serie Financiamiento del Desarrollo 170, Santiago: CEPAL

Tokman, V.E. and Martínez, D. (1999) Flexibilización en el Margen: La Reforma del Contrato de Trabajo, Lima: OIT

Vega-Ruiz, M.L. (2005) La Reforma Laboral: Un Análisis Comparado, Lima: OIT

Yañez, A.M. (1998) 'La Legislación Laboral y su Impacto en la Microempresa: Costos y Desafíos', in E. Chavez, A.M. Yañez, C. Luna, R. De la Flor, S. Fuentes and M. Robles (eds), Perú: El Sector Informal Frente al Reto de la Modernización, International Labour Organization (ILO) 